\title{
Enzyme Hydrolysates of Ginseng Marc Polysaccharides Promote the Phagocytic Activity of Macrophages Via Activation of TLR2 and Mer Tyrosine Kinase
}

\author{
Jeong Yeon Seo ${ }^{1}$, Ji Won Choi ${ }^{1}$, Jae Yeon Lee ${ }^{2}$, Young Shik Park ${ }^{2}$, and Yong Il Park ${ }^{1 *}$ \\ ${ }^{1}$ Department of Biotechnology, The Catholic University of Korea, Bucheon 14662, Republic of Korea \\ ${ }^{2}$ RED Center for Life Science, Biotopia Co., Ltd., Chuncheon 24398, Republic of Korea
}

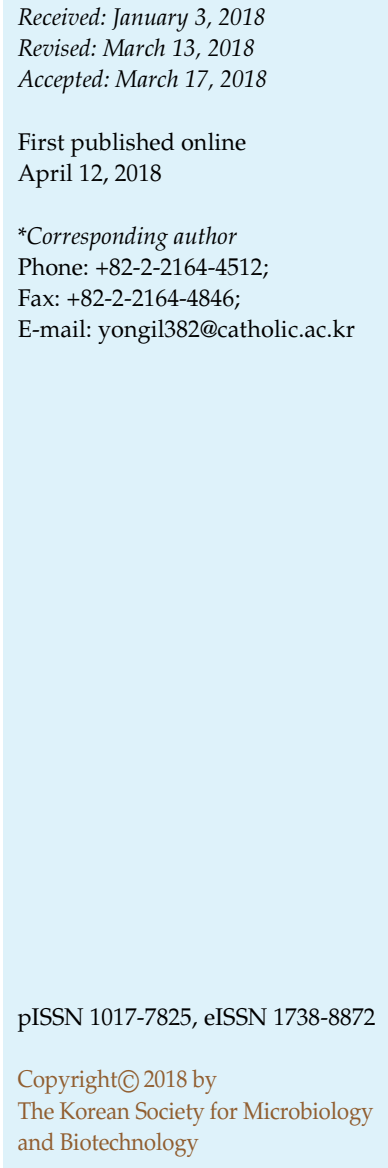

\begin{abstract}
Although ginseng marc is a by-product obtained during manufacturing of various commercial ginseng products and has been routinely discarded as a waste, it still contains considerable amounts of potential bioactive compounds, including saponins and polysaccharides. Previously, we reported that ginseng oligosaccharides derived from ginseng marc polysaccharides by enzymatic hydrolysis exert immunostimulatory activities in macrophages and these activated macrophages are in turn able to inhibit the growth of skin melanoma cells by inducing apoptosis. In the present study, a more detailed investigation of the immunostimulatory activity and underlying action mechanisms of an enzymatic hydrolysate (GEH) containing these oligosaccharides derived from ginseng marc polysaccharides was performed. The levels of proinflammatory cytokines and anti-inflammatory cytokines were measured in GEH-stimulated RAW264.7 macrophages using RT-PCR analysis and ELISA. The expression levels of Toll-like receptor 2 (TLR2) and TLR4, Dectin-1, and MerTK were measured by RT-PCR analysis or western blot analysis, and the phagocytic activities of GEHchallenged bone marrow-derived macrophages toward apoptotic Jurkat cells were assayed using fluorescence microscopy. GEH induced the production of both proinflammatory cytokines TNF- $\alpha$ and IL-6, and anti-inflammatory cytokine IL-10 in RAW 264.7 cells. The expression of the TLR2 and MerTK mRNAs was increased upon GEH treatment. Phagocytosis of apoptotic Jurkat cells was enhanced in GEH-treated macrophages. Based on the results, this enzymatic hydrolysate $(\mathrm{GEH})$ containing oligosaccharides exerts immunostimulatory effects by maintaining the balance between M1 and M2 cytokines, facilitating macrophage activation and contributing to the efficient phagocytosis of apoptotic cells. Therefore, the GEH could be developed as value-added, health-beneficial food materials with immunostimulatory effects.
\end{abstract}

Keywords: Ginseng polysaccharides, enzymatic hydrolysate, ginseng oligosaccharides, immunostimulation, macrophages, Toll-like receptor 2

\section{Introduction}

Panax ginseng C. A. Meyer has been consumed over thousands of years as a medicinal herb to treat various medical symptoms, owing to its various health benefits, such as cardioprotection, vasorelaxation, stimulation of the central nervous system, anticarcinogenic effects, antiallergic effects, and host resistance against infection [1].
Over the last several decades, various active compounds, including ginsenosides, polysaccharides, peptides, polyacetylenic alcohols, and fatty acids, have been isolated and identified from $P$. ginseng and their pharmacological activities have been extensively investigated [1]. Since ginseng-derived functional foods are manufactured and usually sold in the form of water extracts, substantial amounts of ginseng marc are produced after the extraction 
process, which are discarded as wastes or used as animal feeds. However, these wastes contain considerable amounts of bioactive materials, such as polysaccharides and saponins [2]. Acidic polysaccharides found in ginseng marc exhibit significant antitumor effects and immunostimulatory activities [2]. In addition, red ginseng marc containing polysaccharides was used as a potential inhibitor against thermal stress in lipopolysaccharide (LPS)-exposed laying hens [3]. However, it has been generally recognized that the innate structural variations and complexity, high molecular weights, and viscous nature of polysaccharides may limit their successful applications as health-beneficial food materials or therapeutic agents, suggesting that smallersized oligosaccharides would overcome these problems [4]. Indeed, significant efforts have focused on preparing bioactive oligosaccharides from marine polysaccharides, aiming for their pharmaceutical usage [4].

Macrophages are a typical group of immune cells in charge of host defence against bacterial infections. They play an essential role in phagocytosing invading microorganisms, such as viruses and bacteria, as well as dying self cells and cancer cells, and produce many cytokines and inflammatory mediators, such as nitric oxide (NO) and superoxide, when activated by various stimuli [5]. Macrophages connect the innate immunity and adaptive immunity by expressing high levels of class II major histocompatibility complex molecules to present antigens on their surface [6].

We previously reported that glucan-type ginseng oligosaccharides prepared from ginseng marc polysaccharides by enzymatic hydrolysis exert immunostimulatory activities in macrophages, and these activated macrophages are in turn capable of inhibiting the growth of skin melanoma cells by inducing apoptosis [7]. In the present study, in an effort to develop ginseng marc-derived oligosaccharides as potent value-added, health-beneficial materials, an enzymatic hydrolysate containing these oligosaccharides was prepared from ginseng marc polysaccharides and in-depth evaluations of the immunostimulatory activity and underlying action mechanisms were performed.

\section{Materials and Methods}

\section{Materials}

Dulbecco's modified eagle's medium (DMEM), fetal bovine serum (FBS), trypsin-ethylenediaminetetraacetic acid (EDTA), PBS, penicillin, and streptomycin were purchased from GIBCOBRL (USA). 3-(4,5-Dimethylthiazol-2-yl)-2,5-diphenyl tetrazolium bromide (MTT) and dimethyl sulfoxide (DMSO) were purchased from Sigma-Aldrich (USA). Carboxyfluorescein succinimidyl ester (CFSE) and rhodamine-labeled phalloidin were purchased from Invitrogen Life Technologies (USA). Rabbit polyclonal antibodies against phospho-mer tyrosine kinase (p-MerTK) and total MerTK were purchased from FabGennix (USA) and Santa Cruz Biotechnology (USA), respectively.

\section{Preparation of Enzymatic Hydrolysate from the Ginseng Marc}

Ginseng marc powder was purchased from Kotobuki Bussan Co., Ltd. (Japan). Three kilograms of ginseng marc powder was dissolved in $15 \mathrm{~L}$ of distilled water and mixed for $3 \mathrm{~h}$ with gentle stirring. The water-soluble fractions were collected by centrifugation at $14,534 \times g$ for $30 \mathrm{~min}$ and precipitated with 3 volumes of ethanol overnight at $4^{\circ} \mathrm{C}$. The ethanol precipitate was freeze-dried, dissolved in distilled water $\left(\mathrm{dH}_{2} \mathrm{O}\right)$ to achieve a $20 \%$ solution $(\mathrm{w} / \mathrm{v})$, and digested with 100 units of pectinase (Pectinex ultra pulp; Novozymes, Denmark) for $90 \mathrm{~min}$ at $40^{\circ} \mathrm{C}$. The enzyme reaction was stopped by heating the solution at $100^{\circ} \mathrm{C}$ for $10 \mathrm{~min}$. The supernatant was collected after centrifugation at 9,302 $\times g$ for $30 \mathrm{~min}$ and dialyzed (molecular weight cutoff, $10 \mathrm{kDa}$ ) against $\mathrm{dH}_{2} \mathrm{O}$ for $36 \mathrm{~h}$ at $4^{\circ} \mathrm{C}$. After spray-drying, the obtained hydrolysate, with a yield of $12.5 \%$ in dry mass, was tentatively named GEH and used to investigate the immunostimulatory activity and molecular mechanism of action. The endotoxin level in purified GEH was checked by using a chromogenic limulus amebocyte lysate endotoxin assay kit (Genscript, USA), revealing an endotoxin content of less than $0.5 \mathrm{EU} / \mathrm{ml}$ (endotoxin unit/ml).

\section{Chemical Analysis}

The total carbohydrate content was determined using the phenol-sulfuric acid method at $490 \mathrm{~nm}$ [8]. Total proteins and total lipids were quantified using the Bradford method and Bligh and Dyer method, respectively $[9,10]$. The total polyphenol content of GEH was determined using the Folin-Ciocalteu phenol reagent [11].

\section{Analysis of Molecular Mass and Monosaccharide Composition of GEH}

The average molecular mass of the enzymatic hydrolysate (GEH) from ginseng marc was determined by size-exclusion HPLC (Waters Alliance HPLC 2695) with a Shodex OHpak column (SBshodex 804 HQ; Showa Denko Co., Japan). Ten micrograms of 1\% GEH (in $\mathrm{dH}_{2} \mathrm{O}$ ) was injected, eluted with $\mathrm{dH}_{2} \mathrm{O}$ at a flow rate of $0.7 \mathrm{ml} / \mathrm{min}$ at $30^{\circ} \mathrm{C}$, and detected with an ELSD detector (Altech, USA). Pullulans (Sigma-Aldrich, USA) were used as the molecular mass standards: 1,320, 10,000, 21,700, 48,900, 113,000, 200,000, 366,000 , and $804,000 \mathrm{Da}$. The monosaccharide composition of GEH was analyzed by HPAEC-PAD (high-performance anionexchange chromatography pulsed electrochemical detection). One milligram of GEH was dissolved in $1 \mathrm{ml}$ of $\mathrm{dH}_{2} \mathrm{O}$, and trifluoroacetic acid (TFA) was added to obtain a $2 \mathrm{M}$ final concentration and incubated for $4 \mathrm{~h}$ at $100^{\circ} \mathrm{C}$. After the reaction, the mixture was 
vacuum-dried using a Speed-Vac. The GEH was hydrolyzed with 2M TFA for $4 \mathrm{~h}$ at $100^{\circ} \mathrm{C}$, and the vacuum-dried materials were dissolved in $\mathrm{dH}_{2} \mathrm{O}$. Monosaccharides in the TFA-hydrolyzed GEH were analyzed by HPAEC-PAD using a Dionex DX600 chromatography system (Dionex Co., USA) with a Carbo-Pac PA1 column (Dionex Co., USA).

\section{Cell Culture Conditions}

The RAW264.7 murine macrophage cell line (ATCC TIB71) and Jurkat T lymphocyte cell line (ATCC TIB152) were cultured in DMEM and RPMI supplemented with $10 \% \mathrm{FBS}$, penicillin $(100 \mathrm{U} / \mathrm{ml})$, and streptomycin $(100 \mu \mathrm{g} / \mathrm{ml})$. The cells were maintained at $37^{\circ} \mathrm{C}$ in a humidified $5 \% \mathrm{CO}_{2}$ atmosphere. Unless otherwise stated, the cells were incubated with varying concentrations $(100-500 \mu \mathrm{g} / \mathrm{ml})$ of GEH for $24 \mathrm{~h}$. LPS was used as a positive control to prime the macrophages. Bone marrow-derived macrophages (BMDMs) were isolated from the bone marrow of female BALB/c mice (Oriental Bio, Korea) and differentiated in DMEM containing 20\% L929 fibroblast-conditioned medium, according to a previous report [12].

\section{Effects of GEH on Cell Viability}

The MTT assay was conducted to determine the effects of GEH on RAW264.7 cell viability. Cells were seeded on 96-well plates at a density of $1 \times 10^{4}$ cells/well, cultured in DMEM supplemented with $10 \%$ FBS and $1 \%$ penicillin/streptomycin at $37^{\circ} \mathrm{C}$ with $5 \%$ $\mathrm{CO}_{2}$, and treated with different concentrations of GEH (100$500 \mu \mathrm{g} / \mathrm{ml})$. After $24 \mathrm{~h}$ of treatment, the MTT $(1 \mathrm{mg} / \mathrm{ml})$ solution was added to each well and incubated for $4 \mathrm{~h}$ at $37^{\circ} \mathrm{C}$. Intracellular formazan crystals formed by viable cells was solubilized with DMSO and the absorbance was measured at $570 \mathrm{~nm}$ using a microplate reader (Molecular Devices, USA). The percentage viability was calculated using the following equation: (OD of GEHtreated macrophages) $/(\mathrm{OD}$ of control macrophages (untreated) $) \times 100$

\section{Nitric Oxide Assay}

RAW264.7 cells were treated with various concentrations of GEH $(100-500 \mu \mathrm{g} / \mathrm{ml})$ or LPS $(0.1 \mu \mathrm{g} / \mathrm{ml})$ for $24 \mathrm{~h}$. Nitrite concentrations in the supernatant were determined colorimetrically after a reaction with the Griess reagent [13]. Briefly, $100 \mu \mathrm{l}$ of supernatant was mixed with $50 \mu \mathrm{l}$ of $1 \%$ sulfanilic acid in $5 \%$ phosphoric acid and $50 \mu \mathrm{l}$ of $0.1 \%$ naphthylethylene diamine dihydrochloride and incubated for $30 \mathrm{~min}$ at room temperature. The absorbance was measured at $550 \mathrm{~nm}$ using a microplate reader.

\section{Quantitation of Cytokine Levels}

For the measurement of cytokine production, cells were seeded in 6-well plates at a density of $5 \times 10^{5}$ cells/well. After $24 \mathrm{~h}$ of treatment with GEH, the culture supernatants were collected and TNF- $\alpha$, IL- 6 , IFN- $\gamma$, and IL-10 concentrations were measurement using TNF- $\alpha$, IL-6, IFN- $\gamma$, and IL-10 Enzyme-Linked Immunosorbent Assay (ELISA) kits (R\&D Systems, USA), according to the manufacturer's instructions.

\section{Phagocytosis Assay}

BMDMs were plated at $5 \times 10^{4}$ cells / 8 -well chamber slide. After $24 \mathrm{~h}$, the BMDMs were treated with different concentrations of GEH $(100-500 \mu \mathrm{g} / \mathrm{ml})$ and incubated for an additional $48 \mathrm{~h}$. Jurkat $\mathrm{T}$ cells were labeled with CFSE, exposed to UV irradiation at $254 \mathrm{~nm}$ for $10 \mathrm{~min}$ to induce apoptosis, and cultured at $37^{\circ} \mathrm{C}$ for $2.5 \mathrm{~h}$. Approximately $70 \%$ of cells were apoptotic, based on an evaluation of their nuclear morphology using light microscopy [14]. Apoptotic Jurkat T cells were resuspended in DMEM after pelleting by centrifugation, and cocultured with BMDMs at a 4:1 ratio (target to phagocytes). Phagocytosis was allowed for $90 \mathrm{~min}$ at $37^{\circ} \mathrm{C}$. The cells were then washed 4 times with ice-cold PBS to remove the unengulfed apoptotic Jurkat cells and stained with rhodamine-labeled phalloidin according to the manufacturer's instructions. The phagocytosis of apoptotic Jurkat cells by BMDMs was visualized using fluorescence microscopy (Carl Zeiss, Germany, Magnification, ×200).

\section{Reverse-Transcription-PCR (RT-PCR)}

Total RNA was extracted from RAW264.7 cells using TRIzol reagent (Invitrogen Corp., USA), according to the manufacturer's instructions. cDNAs were synthesized from $1 \mu \mathrm{g}$ of total RNA from each sample using a high-capacity cDNA reverse transcription kit (Applied Biosystems, USA) and were amplified with mousespecific primers for TNF- $\alpha$, IL-6, iNOS, IL-10, TLR2, TLR4, Dectin-1, MerTK, and $\beta$-actin. The primer sets and product sizes are listed in Table 1. Each PCR product was separated on $2 \%$ agarose gels, stained with ethidium bromide, and visualized by UV transillumination. All data were collected by densitometry and normalized to the internal control $\beta$-actin.

\section{Western Blot Analysis}

Western blot analyses were performed using lysates from RAW264.7 cells cultured in DMEM in the presence of GEH for the indicated times. The cell lysates were prepared using a cold lysis buffer ( $\mathrm{pH}$ 7.4) containing $20 \mathrm{mM}$ Tris- $\mathrm{HCl}, 150 \mathrm{mM} \mathrm{NaCl}, 1 \mathrm{mM}$ $\mathrm{Na}_{2}$ EDTA, 1 mM EGTA, 1\% NP-40, 1\% sodium deoxycholate, $2.5 \mathrm{mM}$ sodium pyrophosphate, $1 \mathrm{mM} \beta$-glycerophosphate, $1 \mathrm{mM}$ $\mathrm{Na}_{3} \mathrm{VO}_{4}$, and $1 \mu \mathrm{g} / \mathrm{ml}$ of leupeptin. The cell lysates were centrifuged at $13,000 \mathrm{rpm}$ for $10 \mathrm{~min}$ at $4^{\circ} \mathrm{C}$. Protein concentrations were determined using the Bradford method. Equal amounts of protein were separated on 10\% SDS-polyacrylamide gels and transferred to PVDF membranes. The membranes were blocked with Trisbuffered saline (TBS, pH 7.4) containing 5\% nonfat dry milk and incubated with primary anti-rabbit p-MerTK, t-MerTK antibodies, primary anti-mouse p-JNK, p-ERK, p-p38, SOCS3, t-JNK, t-ERK, and t-p38, and $\beta$-tubulin overnight at $4{ }^{\circ} \mathrm{C}$. After washing with TBS containing $0.1 \%$ Tween 20 , the membranes were incubated with anti-rabbit IgG-HRP for $2 \mathrm{~h}$ at room temperature. Specific protein bands were visualized using the enhanced chemiluminescence 
A

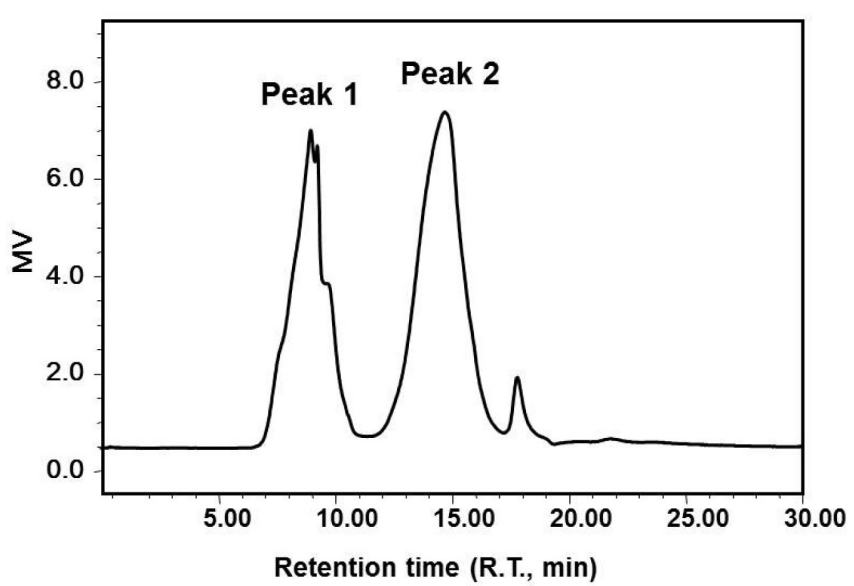

B

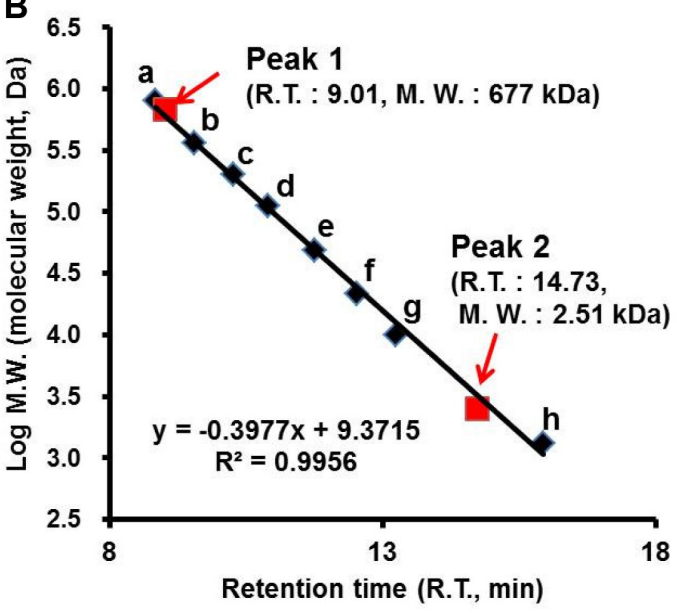

Fig. 1. Determination of the molecular mass of the enzyme hydrolysate (GEH) of ginseng marc.

(A) Size-exclusion HPLC analysis of GEH. (B) Estimation of the molecular mass using pullulans (Sigma) as standard size markers: (a) 804,000, (b) 366,000, (c) 200,000, (d) 113,000, (e) 48,900, (f) 21,700, (g) 10,000, and (h) 1,320 Da. $\mathrm{R}^{2}=0.99$.

system (Amersham Pharmacia Biotech, USA). The intensities of the bands were quantified using the ImageJ program (National Institute of Health, USA). Protein bands were normalized to the corresponding loading controls.

\section{Inhibition Assay against TLR2 or MerTK}

Cells were pretreated with or without a neutralizing antibody against TLR2 or IgG1 $(20 \mu \mathrm{g} / \mathrm{ml}$ each) or MerTK inhibitor UNC2205 (20 nM) for $2 \mathrm{~h}$, followed by further incubation with or without GEH $(500 \mu \mathrm{g} / \mathrm{ml})$ for $24 \mathrm{~h}$. The culture supernatants were collected to analyze levels of TNF- $\alpha$, IL- 6 , and IL-10 using ELISAs.

\section{Statistical Analysis}

Data were analyzed using SAS software (SAS Institute, Inc., USA). All values were expressed as the mean \pm SEM, and measurements were performed in triplicate. Statistical differences among groups were evaluated using one-way analysis of variance followed by Dunnett's multiple range tests.

Table 1. Primer sequences and product sizes.

\begin{tabular}{|c|c|c|c|}
\hline Primers & Forward/Reverse & Sequence & Product size (bp) \\
\hline \multirow[t]{2}{*}{ iNOS } & Forward & 5'-GGGAGTAGCCTGTGTGCACCTGGAA-3' & 310 \\
\hline & Reverse & 5'-CTGCAGCACTTGGATCAGGAACCTG-3' & \\
\hline $\mathrm{TNF}-\alpha$ & Reverse & 5'-GCAAAAGAGGAGGCAACAAG-3' & \\
\hline \multirow[t]{2}{*}{ IL-10 } & Forward & 5'-CCAAGCCTTATCGGAAATGA-3' & 162 \\
\hline & Reverse & 5'-TTTTCACAGGGGAGAAATCG-3' & \\
\hline \multirow[t]{2}{*}{ IL-6 } & Forward & 5'-GTTCTCTGGGAAATCGTGGA-3' & 397 \\
\hline & Reverse & 5'-TGGTCTTGGTCCTTAGCCAC-3' & \\
\hline \multirow[t]{2}{*}{ TLR2 } & Forward & 5'-AGCATCCGAATTGCATCACC-3' & 175 \\
\hline & Reverse & 5'-ACCCCAGAAGCATCACATGA-3' & \\
\hline \multirow[t]{2}{*}{ TLR4 } & Forward & 5'-TTGCTGCCAACATCATCCAG-3' & 359 \\
\hline & Reverse & 5'-GGTCCAAGTTGCCGTTTCTT-3’ & \\
\hline Dectin-1 & Reverse & 5'-TGGCCAGACAGCATAAGGAA-3' & \\
\hline \multirow[t]{2}{*}{ MerTK } & Forward & 5'-TCCTACCTCCTGTTGCGTTT-3' & 356 \\
\hline & Reverse & 5'-ATTCACACTCTCAGGCTGCT-3' & \\
\hline \multirow[t]{2}{*}{$\beta$-Actin } & Forward & 5'-TGGAATCCTGTGGCATCCATGAAAC-3' & 463 \\
\hline & Reverse & 5'-TAAAACGCAGCTCAGTAACAGTCCG-3' & \\
\hline
\end{tabular}


Table 2. Chemical composition of the enzyme hydrolysate (GEH) of ginseng marc.

\begin{tabular}{|c|c|c|c|c|c|c|c|c|}
\hline \multirow[t]{2}{*}{ Source } & \multirow{2}{*}{$\begin{array}{c}\text { Carbohydrate }^{a} \\
(\text { mass \%) }\end{array}$} & \multirow{2}{*}{$\begin{array}{l}\text { Protein }^{\mathrm{b}} \\
\text { (mass \%) }\end{array}$} & \multirow{2}{*}{$\begin{array}{c}\text { Lipid }^{\mathrm{c}} \\
\text { (mass \%) }\end{array}$} & \multirow{2}{*}{$\begin{array}{l}\text { Polyphenol }^{\mathrm{d}} \\
\text { (mass \%) }\end{array}$} & \multicolumn{4}{|c|}{$\begin{array}{c}\text { Neutral sugars }{ }^{\mathrm{e}} \\
\text { (mol\% of all neutral sugars) }\end{array}$} \\
\hline & & & & & Glc & Gal & Ara & Rha \\
\hline GEH & 79.79 & 1.3 & 0.26 & 0.56 & 82.4 & 7.4 & 7.1 & 3.0 \\
\hline
\end{tabular}

${ }^{\mathrm{a}}$ Total carbohydrate was determined by the phenol-sulfuric acid method at $490 \mathrm{~nm}$ [8].

${ }^{\mathrm{b}}$ Total protein was quantified by the Bradford method [9].

${ }^{\mathrm{c}}$ Total lipids content was determined by the Bligh and Dyer method [10].

${ }^{\mathrm{d}}$ Total polyphenols was determined using the Folin-Ciocalteu phenol reagent [11].

${ }^{e}$ Neutral sugar composition was analyzed using HPEAC-PAD.

\section{Results and Discussion}

\section{Chemical Composition of GEH and Molecular Weight Determination}

The size-exclusion HPLC analysis showed that the enzyme hydrolysate $(\mathrm{GEH})$ of the ginseng marc polysaccharides consists of two major fractions with estimated molecular sizes of $677,720 \mathrm{Da}(42.28 \%$ relative amount) and 2,515 Da $(57.72 \%)$, respectively (Figs. $1 \mathrm{~A}$ and $1 \mathrm{~B})$. As shown in Table 2, chemical composition analyses showed that GEH consists mainly of carbohydrates $(79.79 \%$, in mass) and other minor chemicals, such as protein (1.3\%, in mass), lipids $(0.26 \%)$, and polyphenols $(0.56 \%)$. The monosaccharide analysis showed that GEH mainly consists of glucose $(82.4 \mathrm{~mol} \%)$ as the major sugar and other sugars, such as galactose (7.4), arabinose (7.1), and rhamnose (3.0). These results suggested that the GEH has water-soluble arabinogalactoglucan-type polymers mainly consisting of glucose residues with other minor sugars.

\section{Effects of GEH on the Viability of RAW264.7 Cells}

As an initial study of the immunostimulory activitiy of GEH in RAW 264.7 macrophage cells, the effects of GEH on the viability of RAW264.7 cells that had been cultured with GEH $(100-500 \mu \mathrm{g} / \mathrm{ml})$ for $24 \mathrm{~h}$ were assessed using MTT assay. As shown in Fig. 2A, GEH did not disturb the viability of RAW264.7 macrophages at concentrations up to $500 \mu \mathrm{g} / \mathrm{ml}$, but rather enhanced cell proliferation in a dosedependent manner, with $7.30 \%, 16.05 \%$, and $20.72 \%$ increases, suggesting that the GEH is nontoxic toward RAW264.7 macrophages.

\section{Effects of GEH on the Production of Immunomodulatory} Molecules in RAW264.7 Cells

Whether GEH improves the immune functions in RAW264.7 cells was examined. The expression levels of iNOS, TNF- $\alpha$, and IL-10 mRNAs in GEH-treated RAW264.7 cells were examined by RT-PCR at various time points. The expression of the iNOS mRNA was significantly increased in a time-dependent manner, and its expression reached a peak at $24 \mathrm{~h}$ of incubation with $500 \mu \mathrm{g} / \mathrm{ml}$ of GEH (Fig. 2B). The GEH $(100,250$, and $500 \mu \mathrm{g} / \mathrm{ml})$ induced dose-dependent increases in the expression of the iNOS mRNA by 7.20-, 7.81-, and 8.25-fold and the protein levels by 1.98-, 2.26-, and 2.47-fold, respectively, and the NO release was also dose-dependently increased by $1.75 \%, 11.2 \%$, and $39.1 \%$, respectively (Fig. 3). The expression of TNF- $\alpha$ and IL-10 mRNAs peaked at $4 \mathrm{~h}$ of incubation and was gradually decreased in a time-dependent manner (Figs. 2C and 2D). After $4 \mathrm{~h}$ of exposure, GEH dose-dependently increased the expression of the TNF- $\alpha$, IL-6, and IL-10 mRNAs in RAW264.7 cells (Fig. 4). The expression of the TNF- $\alpha$ mRNA increased by $6.3 \%, 8.1 \%, 10.7 \%$ compared to GEHuntreated control cells $(0 \mu \mathrm{g} / \mathrm{ml})$. In addition, TNF- $\alpha$ production was dose-dependently and significantly increased in the supernatant of GEH-treated RAW264.7 cells by 8.9-, 13.9-, and 16.6-fold, consistent with the mRNA expression data shown in Fig. 4A (Fig. 5A). Similarly, the levels of the IL-6 mRNA and protein were dose-dependently increased by the GEH treatment (11.4-, 36.8-, and 47.2-fold increases in the mRNA levels; and 2.6-, 16.9-, and 120.2-fold increases in protein release by 100,250 , and $500 \mu \mathrm{g} / \mathrm{ml} \mathrm{GEH}$ treatment; Figs. 4B and 5B). Similar results were obtained in GEHtreated BMDMs (data not shown).

Macrophages are the most functionally diverse cells of the hematopoietic system and are found in almost every tissue. In recent decades, the new concept of macrophage polarization, which classifies macrophages into M1 (classically activated) macrophages or M2 (alternatively activated) macrophages, was proposed by Mills et al. [15] and has received great attention from researchers. In addition to their classical role of killing the attacking microorganisms, macrophages are also involved in the induction and resolution of inflammation, as well as tissue 
A
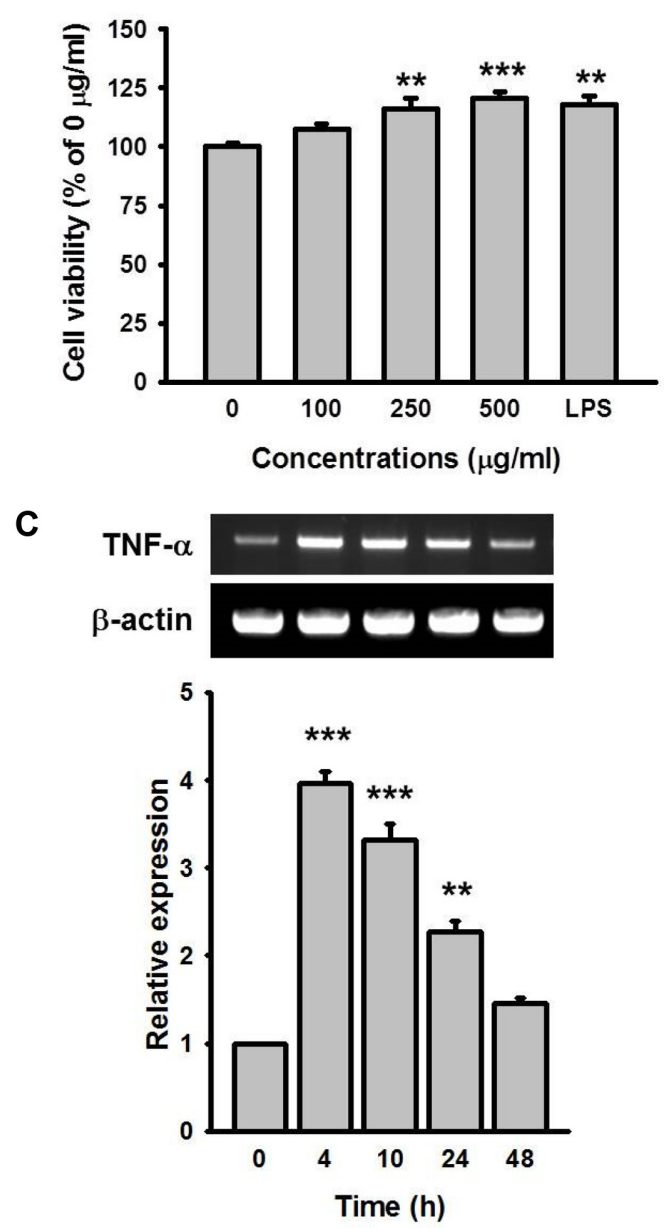

B
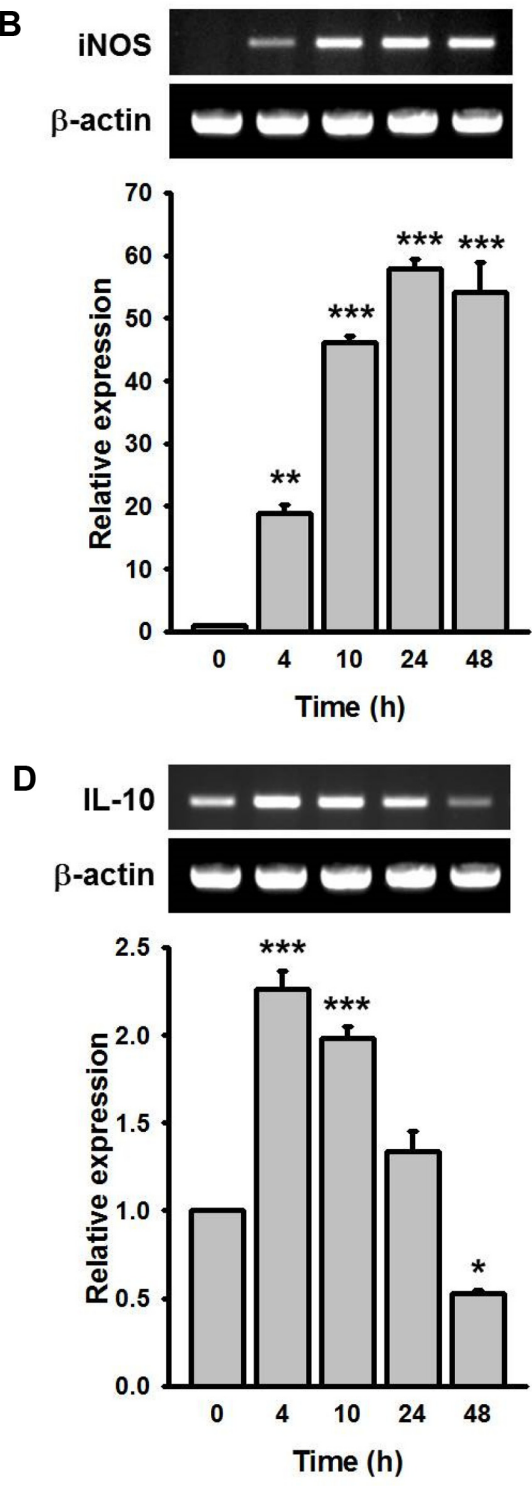

Fig. 2. Effects of GEH on the cell viability and the expression of iNOS, TNF- $\alpha$, and IL-10 mRNAs in RAW264.7 macrophages. (A) Cells were cultured in the presence of GEH $(100-500 \mu \mathrm{g} / \mathrm{ml})$ or LPS $(0.1 \mu \mathrm{g} / \mathrm{ml})$ for $24 \mathrm{~h}$, and the cell viability was determined by MTT assay. (B, C, D) The expression of iNOS (B), TNF- $\alpha$ (C), and IL-10 (D) mRNAs was measured using RT-PCR. Relative increases in the levels of each band compared with the loading control $\beta$-actin were quantified using densitometry and ImageJ software. Values are expressed as the mean \pm SEM of three separate experiments. ${ }^{*} p<0.05,{ }^{* *} p<0.01$ and ${ }^{* * *} p<0.001$ compared with the GEH-untreated cells $(0 \mu \mathrm{g} / \mathrm{ml})$.

repair. The M1 subtype exhibits inflammatory functions and more effectively presents antigens to the adaptive immune system, whereas M2 macrophages show immunosuppressive and anti-inflammatory functions, contribute to tissue remodeling, and promote Th2-mediated immune responses [16].

Since TNF- $\alpha$ and IL-6 are regarded as typical proinflammatory cytokines secreted by M1 macrophage, the increase in the mRNA and protein levels of these cytokines, shown in Figs. 4 and 5, indicate that they are hallmarks of classic macrophage activation and a possible excessive immune reaction. In addition, a report using an anti-TNF- $\alpha$ antibody-administered mouse model showed that the TNF- $\alpha$ depleted mouse showed significant reduction in illness and delayed clearance of respiratory syncytial virus (RSV)infected cells, suggesting that TNF- $\alpha$ is important for the induction of an immune response, but it exacerbates illness during the effector phase of RSV infection [17]. Therefore, 
A
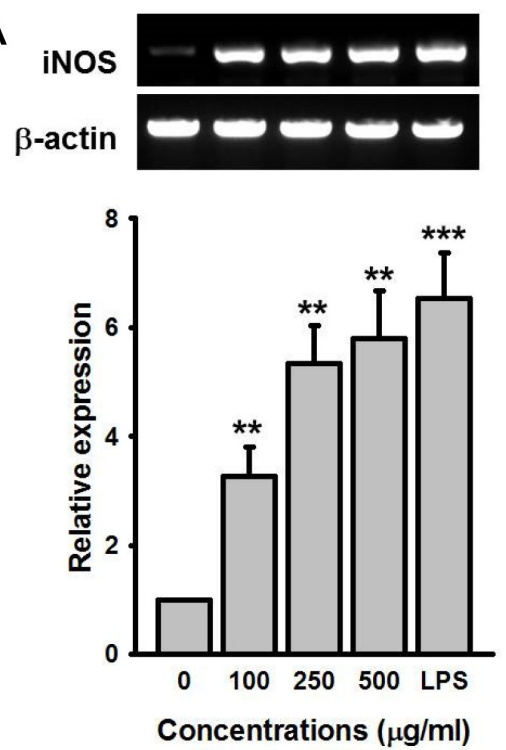

B
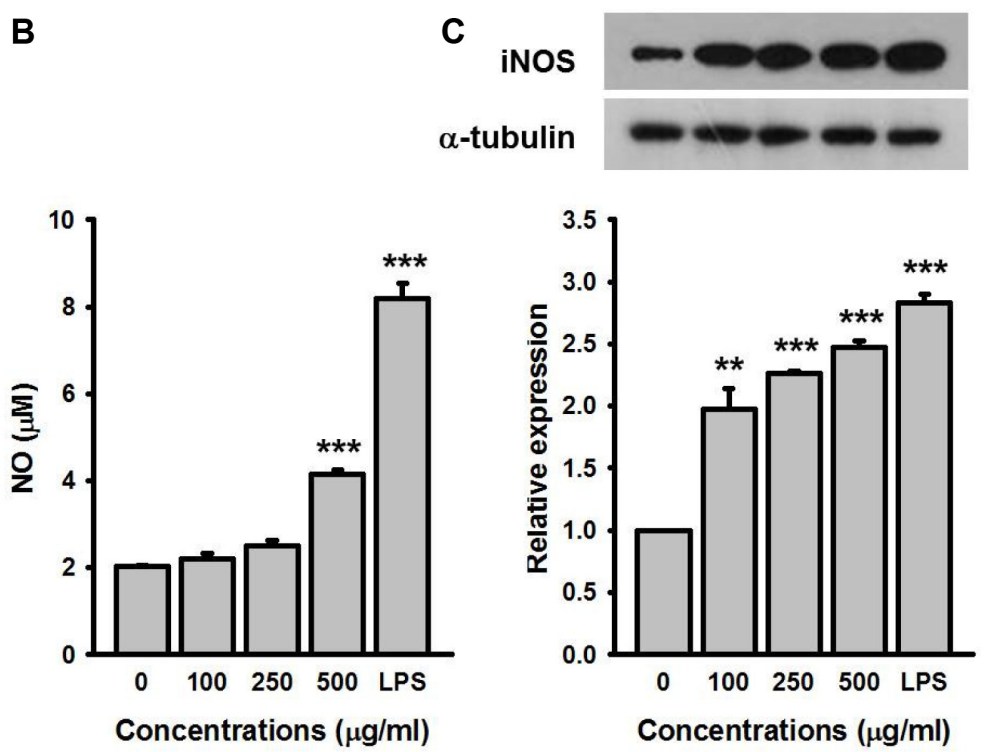

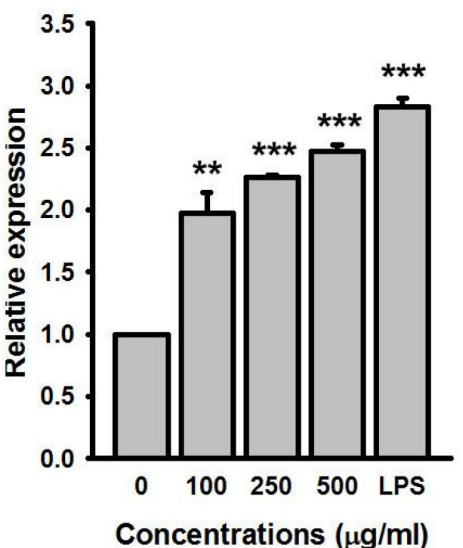

Fig. 3. Effects of GEH on nitric oxide (NO) levels in RAW264.7 macrophages.

Cells were cultured with or without GEH $(0-500 \mu \mathrm{g} / \mathrm{ml})$ or LPS $(0.1 \mu \mathrm{g} / \mathrm{ml})$ for $24 \mathrm{~h}$. The expression of the iNOS mRNA $(\mathbf{A})$ and protein $(\mathbf{C})$ was measured using RT-PCR and western blot analysis, respectively. Relative increases in the levels of each band compared with the loading control $\beta$-actin or $\beta$-tubulin were quantified using densitometry and ImageJ software. (B) NO levels in the culture supernatants were analyzed using Griess reagent. Values are expressed as the mean \pm SEM of three separate experiments. ${ }^{* *} p<0.01$ and ${ }^{* * *} p<0.001$ compared with the GEHuntreated cells $(0 \mu \mathrm{g} / \mathrm{ml})$.

if these excessive proinflammatory cytokines TNF- $\alpha$ and IL-6 are continuously produced in the body and are not controlled appropriately and promptly, chronic inflammation may eventually occur and the resolution of inflammation
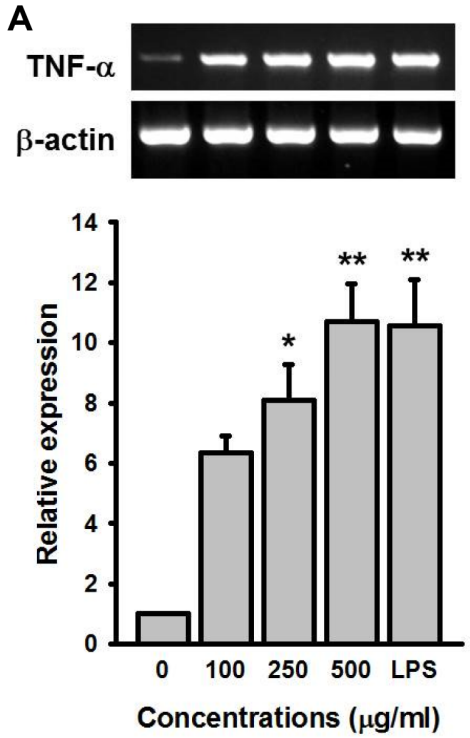

B
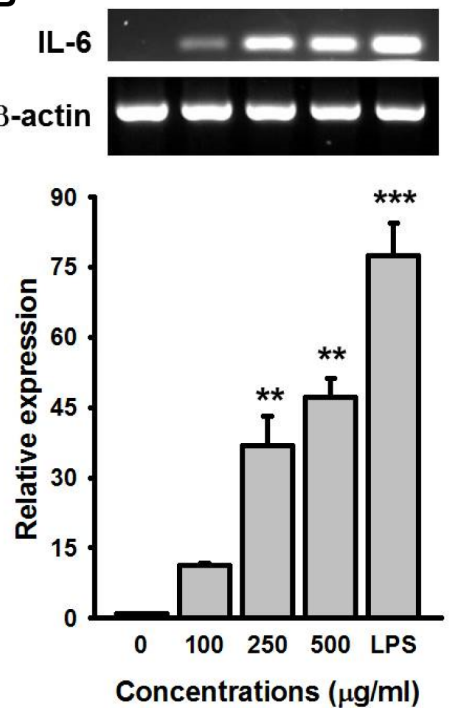
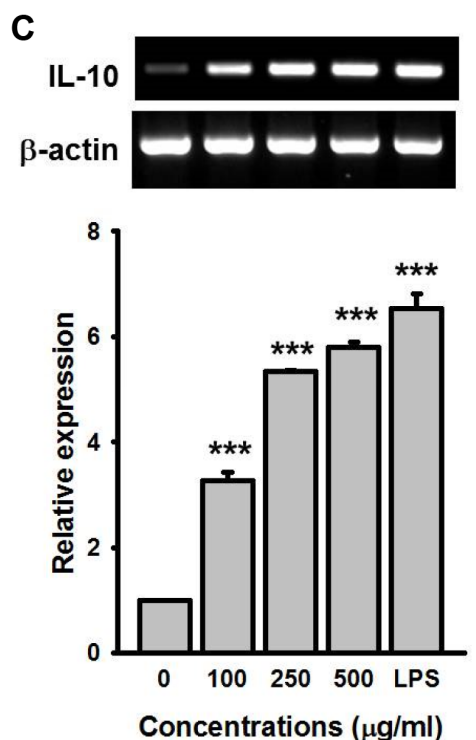

Fig. 4. Effects of GEH on the expression of TNF- $\alpha$, IL-6, and IL-10 mRNAs in RAW264.7 macrophages.

Cells were cultured with or without GEH $(0-500 \mu \mathrm{g} / \mathrm{ml})$ for $4 \mathrm{~h}$. The expression of the TNF- $\alpha$ (A), IL-6 (B), and IL-10 (C) mRNAs was analyzed using RT-PCR. Relative increases in the levels of each band compared with the loading control $\beta$-actin were quantified using densitometry and ImageJ software. Values are expressed as the mean \pm SEM of three separate experiments. ${ }^{*} p<0.05,{ }^{* *} p<0.01$, and ${ }^{* * *} p<0.001$ compared with the GEH-untreated cells $(0 \mu \mathrm{g} / \mathrm{ml})$. 

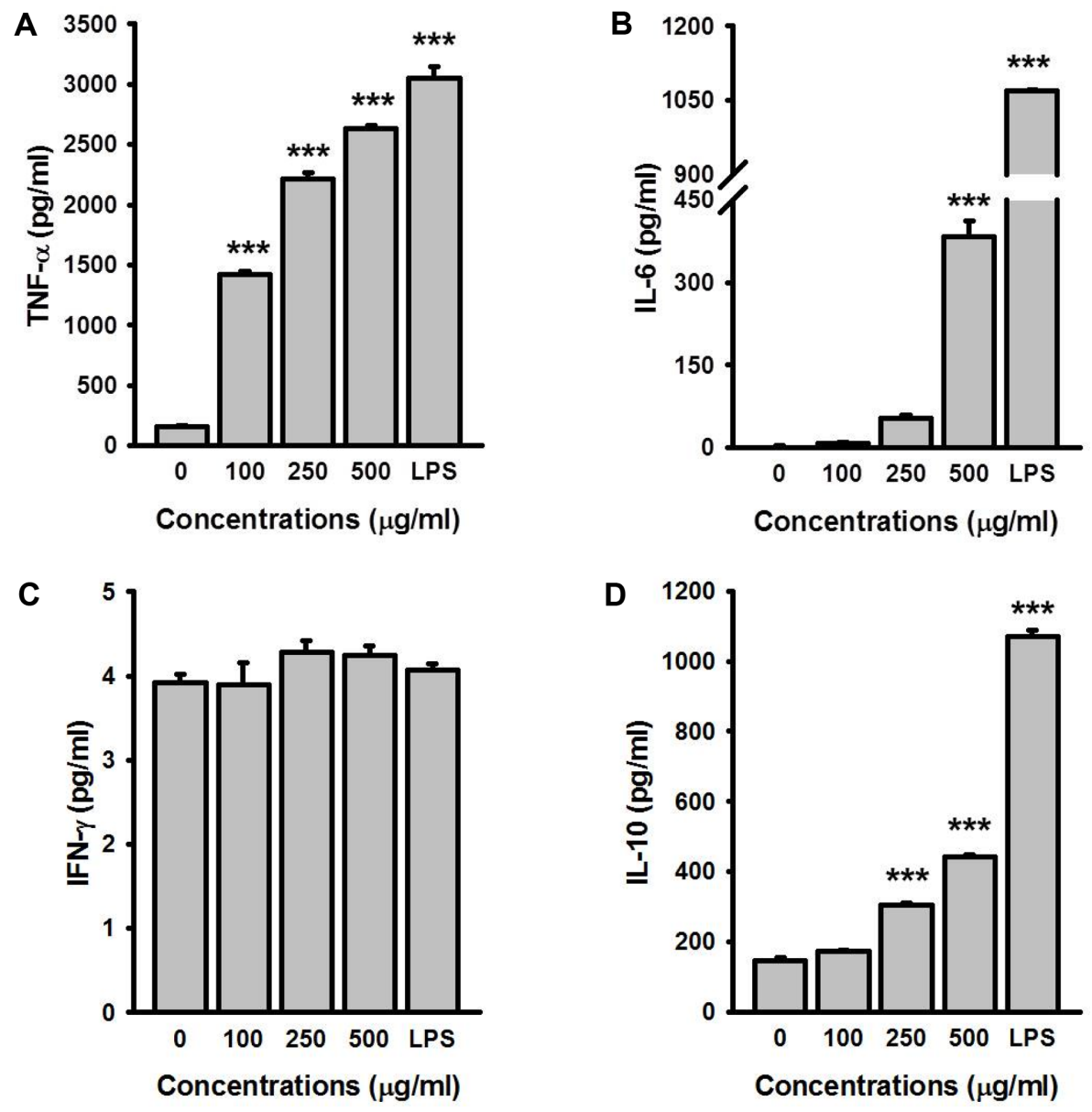

Fig. 5. Effects of GEH on TNF- $\alpha$, IL-6, IFN- $\gamma$, and IL-10 production in RAW264.7 macrophages.

Cells were cultured with or without GEH $(100-500 \mu \mathrm{g} / \mathrm{ml})$ or LPS $(0.1 \mu \mathrm{g} / \mathrm{ml})$ for $24 \mathrm{~h}$. The culture supernatants were analyzed for levels of TNF- $\alpha$ (A), IL-6 (B), IFN- $\gamma\left(\right.$ C), and IL-10 (D) using ELISAs. Values are expressed as the mean \pm SEM of three separate experiments. ${ }^{* * *} p<0.001$ compared with the GEH-untreated cells $(0 \mu \mathrm{g} / \mathrm{ml})$.

will be delayed or inhibited. Therefore, potential questions have been raised regarding whether the increase in GEHelicited TNF- $\alpha$ expression at both the transcriptional and translational levels is a representative sign of immune stimulation or an excessive pro-inflammatory status in macrophages. Changes in the mRNA and protein levels of the M2-generated cytokine IL-10 were investigated in GEH-treated macrophage to address this question. As shown in Figs. 4C and 5D, the expression of the IL-10 mRNA was significantly and dose-dependently increased by 3.3-, 5.3-, and 5.8-fold following treatment with various concentrations of GEH (100, 250, and $500 \mu \mathrm{g} / \mathrm{ml}$, respectively), and its protein level was considerably increased by 1.2-, 2.1-, and 3.0-fold, respectively, compared with GEHuntreated normal controls, suggesting that M1 cytokines, such as TNF- $\alpha$, and M2 cytokines, such as IL-10, are both produced in RAW264.7 cells in the presence of GEH. This indicates that the M1/M2 balance is not disturbed by the $\mathrm{GEH}$ treatment, and rather is maintained.

\section{Effects of GEH on the Expression of Toll-Like Receptor} mRNAs in RAW264.7 Cells

Next, the molecular target of GEH was investigated using RT-PCR to identify the molecular mechanism by which GEH exerts its immunostimulatory effects on macrophages. Owing to its large size, GEH is presumed to be unable to penetrate the cell, thus it probably transduces its signal through pattern recognition receptors expressed on the surface of macrophages. The mRNA levels of surface receptors, such as TLR2, TLR4, and Dectin-1, were determined in GEH-treated macrophages. As shown in Fig. 7A, the expression of the TLR2 mRNA was dose- 

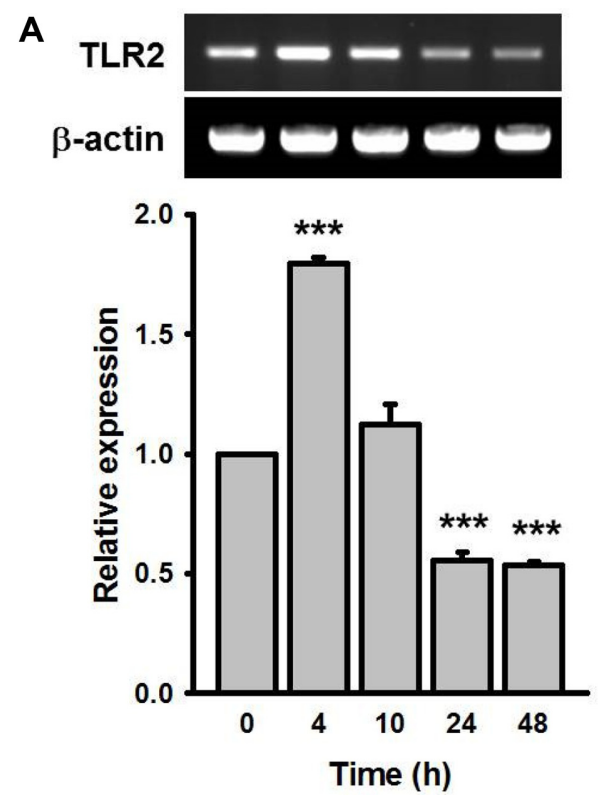

B
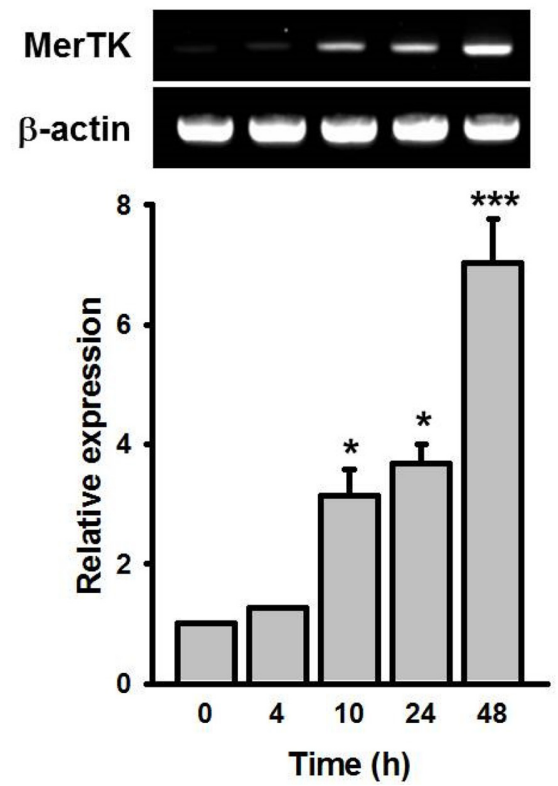

Fig. 6. Effects of GEH on the expression of TLR2 and MerTK mRNAs.

The expression of the TLR2 (A) and MerTK (B) mRNAs was analyzed using RT-PCR. Relative increases in the levels of each band compared with the loading control $\beta$-actin were quantified using densitometry and ImageJ software. Values are expressed as the mean \pm SEM of three separate experiments. ${ }^{*} p<0.05$ and ${ }^{* * *} p<0.001$ compared with the GEH-untreated cells $(0 \mathrm{~h})$.

dependently increased by 2.6-, 3.2-, and 4.8-fold in response to the GEH treatment $(100,250$, and $500 \mu \mathrm{g} / \mathrm{ml})$. The TLR2 mRNA levels peaked after $4 \mathrm{~h}$ of exposure to GEH, returned to basal levels within $10 \mathrm{~h}$, and decreased below the basal levels (Fig. 6A). Unlike TLR2, the mRNA levels of TLR4 and Dectin-1 were not altered by different concentrations
A

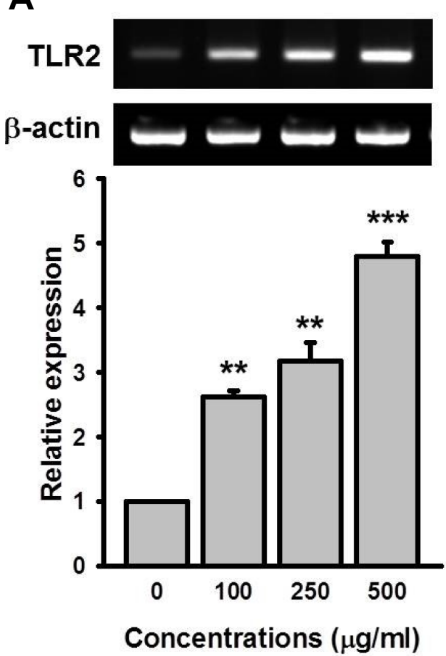

B

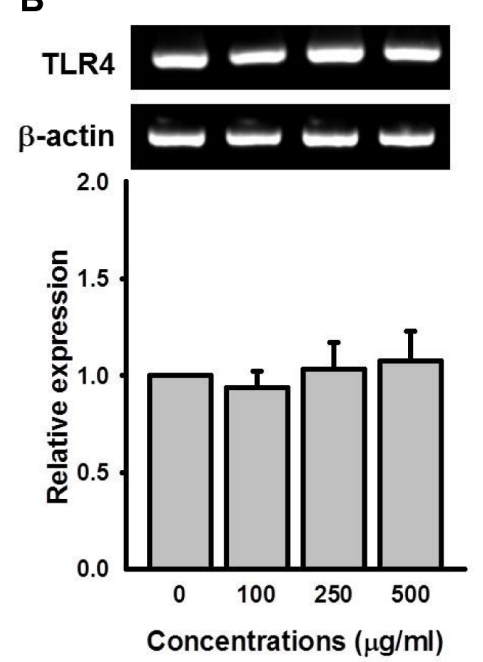

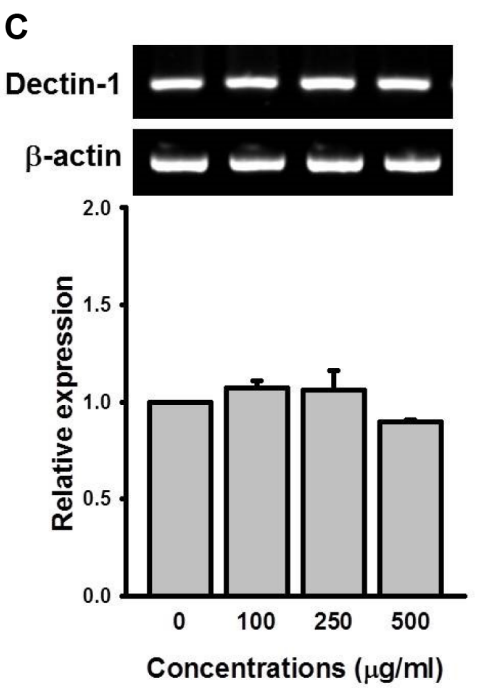

Fig. 7. Effects of GEH on the expression of TLR2, TLR4, and Dectin-1 mRNAs in RAW264.7 macrophages.

Cells were cultured with or without GEH (100-500 $\mu \mathrm{g} / \mathrm{ml})$ for $4 \mathrm{~h}$. The expression of the TLR2 (A), TLR4 (B), and Dectin-1 (C) mRNAs was analyzed using RT-PCR. Relative increases in the levels of each band compared with the loading control $\beta$-actin were quantified using densitometry and ImageJ software. Values are expressed as the mean \pm SEM of three separate experiments. ${ }^{* *} p<0.01$ and ${ }^{* * *} p<0.001$ compared with the GEH-untreated cells $(0 \mu \mathrm{g} / \mathrm{ml})$. 
of GEH (Figs. 7B and 7C). Dectin-1, a C-type lectin receptor on macrophages, monocytes, and dendritic cells, recognizes the fungal wall-derived $\beta$-glucan found at high levels in mushrooms and promotes the phagocytosis of live yeast and fungal-derived zymosan [18]. Thus, GEH may interact with TLR2, but not with TLR4 or Dectin-1, on the surface of macrophages, transduce signals inside the cell, and ultimately induce the production of immunostimulatory mediators, such as TNF- $\alpha$, IL-6, NO, and IL-10.

\section{GEH Enhances Phygocytotic Activities of Macrophages toward Apoptotic Cells}

The human body efficiently removes more than $10^{9}$ apoptotic cells everyday using the TAM receptors (Tyro3, Axl, and MerTK) on macrophages and dendritic cells [19]. If these cells are not removed rapidly, inflammation persists owing to the release of various inflammatory molecules from the debris of dying cells.

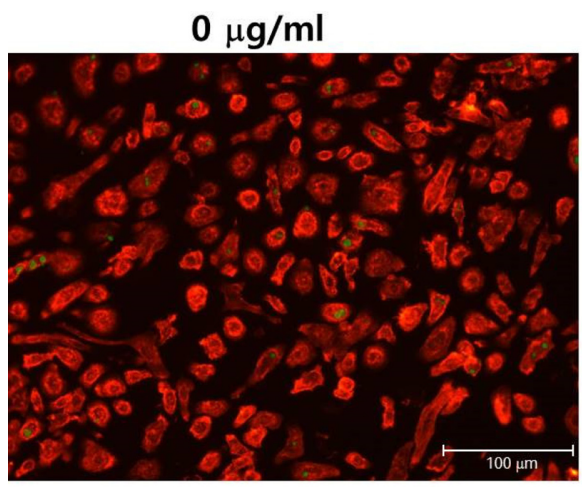

$250 \mu \mathrm{g} / \mathrm{ml}$

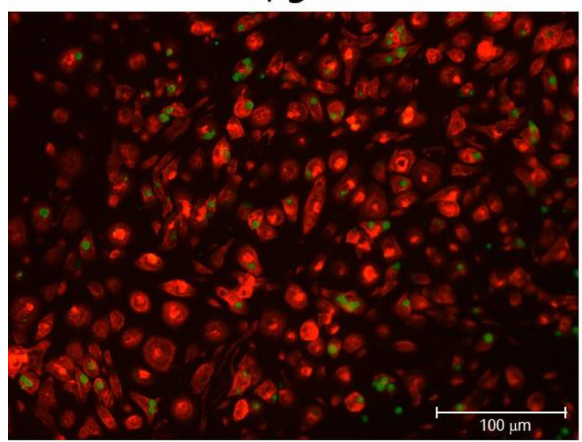

The phagocytic activity of macrophages toward apoptotic Jurkat cells was assayed using CFSE-labeled Jurkat cells to address this question. As shown in Fig. 8, phagocytosed apoptotic Jurkat cells, shown in green, gradually appeared inside the rhodamine-phalloidin-labeled BMDMs in response to the increasing concentrations of GEH, suggesting that GEH is definitely capable of activating macrophages to engulf apoptotic cells. $\beta$-Glucan has been shown to stimulate BMDMs to recognize phosphatidylserine, which is exposed on apoptotic cells, and thereby enhance the phagocytosis of apoptotic cells [20]. Similar to this report, our data demonstrated that GEH stimulates macrophages to remove the apoptotic cells.

\section{Effects of GEH on MerTK in RAW264.7 Cells}

The TAM receptor tyrosine kinase has been known to play a pivotal role in resolution of inflammation [21]. Mice deficient in MerTK/Axl/Tyro3 produce autoantibodies
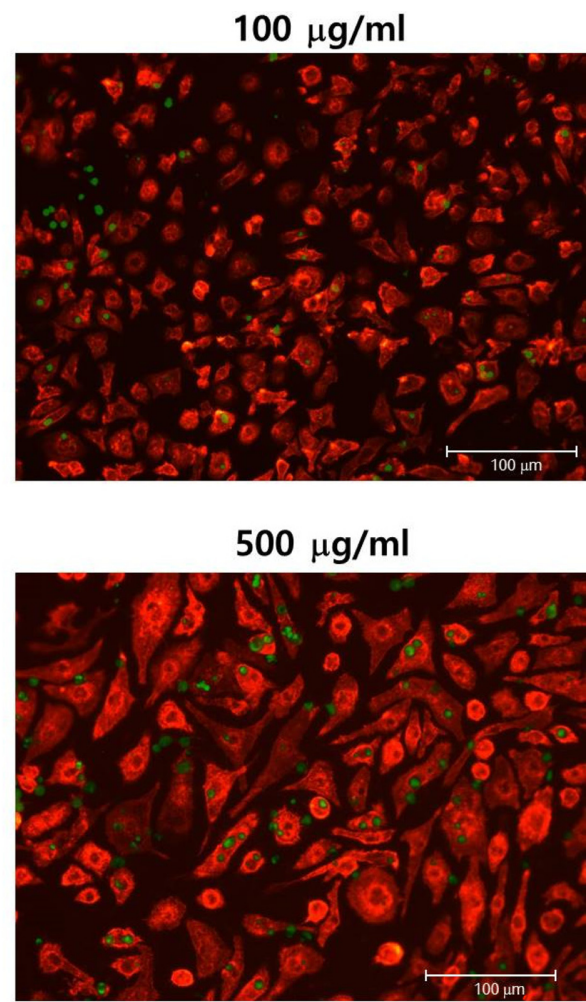

Fig. 8. Effects of GEH on MerTK mRNA and protein levels in RAW264.7 macrophages.

(A) Cells were cultured with or without GEH $(0-500 \mu \mathrm{g} / \mathrm{ml})$ for $24 \mathrm{~h}$ and expression of the MerKT mRNA was measured using RT-PCR. (B) RAW 264.7 cells were challenged with or without GEH $(100-500 \mu \mathrm{g} / \mathrm{ml})$ for $48 \mathrm{~h}$ and apoptotic Jurkat cells were co-cultured with RAW264.7 cells at a 10:1 ratio for $15 \mathrm{~min}$. After removing the unengulfed Jurkat cells by washing with ice-cold PBS, lysates were prepared by RIPA lysis buffer. The phospho-MerTK (p-MerTK) and total MerTK (t-MerTK) levels were monitored by Western blot analyses. Relative increases in the levels of each band compared to $\beta$-actin or t-MerTK were quantified using densitometry and ImageJ software. Values are expressed as the means $\pm \mathrm{SEM}$ of three separate experiments. ${ }^{*} p<0.05$ and ${ }^{* *} p<0.01$ compared with the GEH-untreated cells $(0 \mu \mathrm{g} / \mathrm{ml})$. 
A
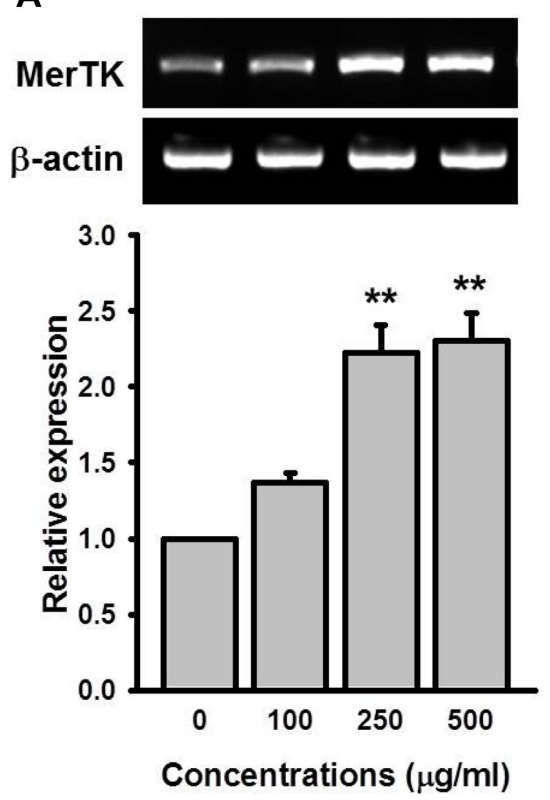

B
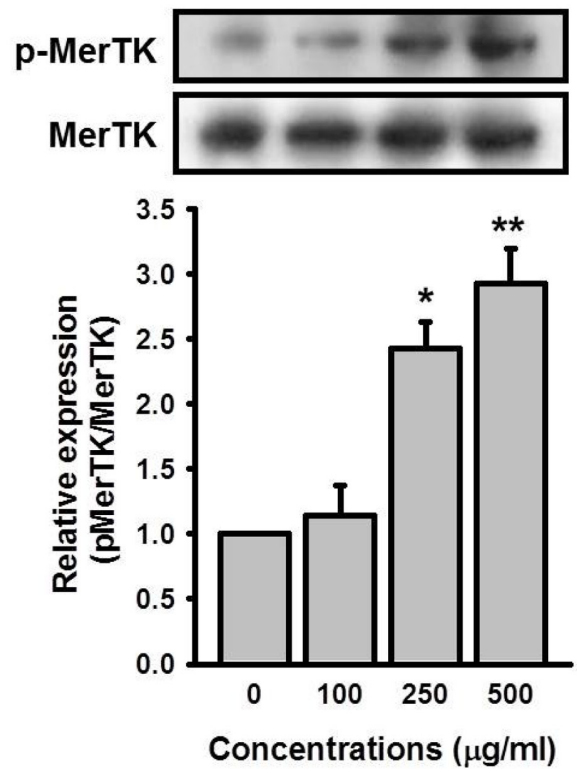

Fig. 9. Effects of GEH on MerTK mRNA and protein levels in RAW264.7 macrophages.

(A) Cells were cultured with or without GEH $(0-500 \mu \mathrm{g} / \mathrm{ml})$ for $24 \mathrm{~h}$ and expression of the MerKT mRNA was measured using RT-PCR. (B) RAW264.7 cells were challenged with or without GEH $(100-500 \mu \mathrm{g} / \mathrm{ml})$ for $48 \mathrm{~h}$ and apoptotic Jurkat cells were cocultured with RAW264.7 cells at a 10:1 ratio for $15 \mathrm{~min}$. After removing the unengulfed Jurkat cells by washing with ice-cold PBS, lysates were prepared with RIPA lysis buffer. The phospho-MerTK (p-MerTK) and total MerTK ( $\mathrm{t}$-MerTK) levels were monitored by western sblot analyses. Relative increases in the levels of each band compared with $\beta$-actin or t-MerTK were quantified using densitometry and ImageJ software. Values are expressed as the mean \pm SEM of three separate experiments. ${ }^{*} p<0.05$ and ${ }^{* *} p<0.01$ compared with the GEH-untreated cells $(0 \mu \mathrm{g} / \mathrm{ml})$.

that spontaneously lead to development of autoimmune diseases, including rheumatoid arthritis and lupus, and are associated with chronic inflammation [19]. Macrophages derived from MerTK-negative mice show an approximately $40-50 \%$ reduction in the phagocytosis of apoptotic thymocytes [22]. The effect of GEH on changes in MerTK expression at both the mRNA and protein levels were investigated using RT-PCR and western blot analyses. As shown in Fig. 9A, the expression of the MerTK mRNA was significantly increased by increasing concentrations of GEH $(100-500 \mu \mathrm{g} / \mathrm{ml})$. Similar to the increased mRNA expression, apoptotic Jurkat cells significantly induced MerTK phosphorylation in GEH-activated macrophages in a dose-dependent manner, with 1.14-, 2.43-, and 2.93-fold increases compared with the GEH-untreated normal control $(0 \mu \mathrm{g} / \mathrm{ml})$, suggesting that $\mathrm{GEH}$ is capable of eliciting MerTK activation to facilitate the subsequent clearance of apoptotic cells.

GEH Stimulates RAW264.7 Cells to Produce TNF- $\alpha$, IL-6, and IL-10 via TLR2 or MerTK Activation

To confirm the roles of TLR2 and MerTK in activation of macrophage function, cells were pretreated with or without the TLR2 neutralizing antibody or MerTK inhibitor, followed by further incubation with or without GEH $(500 \mu \mathrm{g} / \mathrm{ml})$ for $24 \mathrm{~h}$. Pretreatment with the neutralizing antibody against TLR2 significantly alleviated cytokine production of TNF- $\alpha$, IL- 6 , and IL-10 in GEH-treated RAW 264.6 cells (Figs. 10A-10C). In addition, the MerTK inhibitor (UNC2205) significantly reduced GEH-induced cytokine production of TNF- $\alpha$, IL- 6 , and IL-10 compared with GEHtreated cells (Figs. 10D-10F). It has been reported that overexpression of MerTK in epithelial cancer cells drives the clearance of apoptotic cells [23]. In contrast, homozygous deletion of MerTK results in systemic autoimmunity from the failure to clear apoptotic cells by myeloid cells in peripheral tissues $[24,25]$. In our study, GEH activated macrophage functions to produce TNF- $\alpha$, IL-6, and IL-10, thereby enhancing phagocytosis of apoptotic cells as shown in Figs. 5 and 8. As shown in Fig. 10, inhibition assay using the TLR2 neutralizing antibody and MerTK inhibitor definitely showed that these cytokine productions in GEH-stimulated RAW264.7 cells are mediated by TLR2 and MerTK, even though TLR2 and MerTK did not 


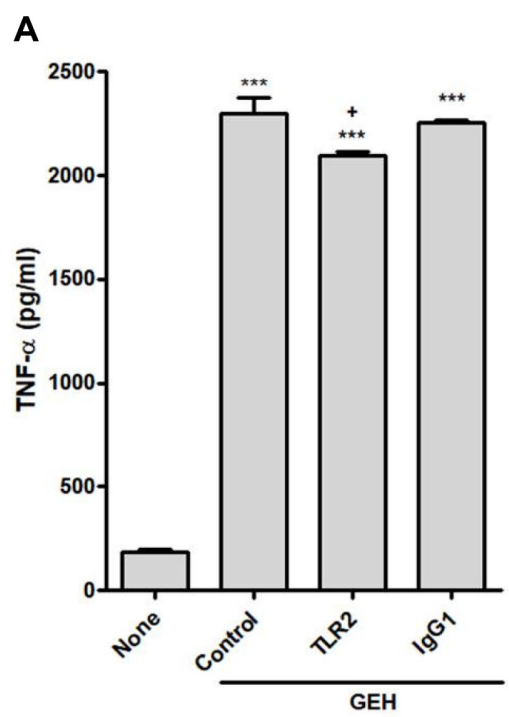

B
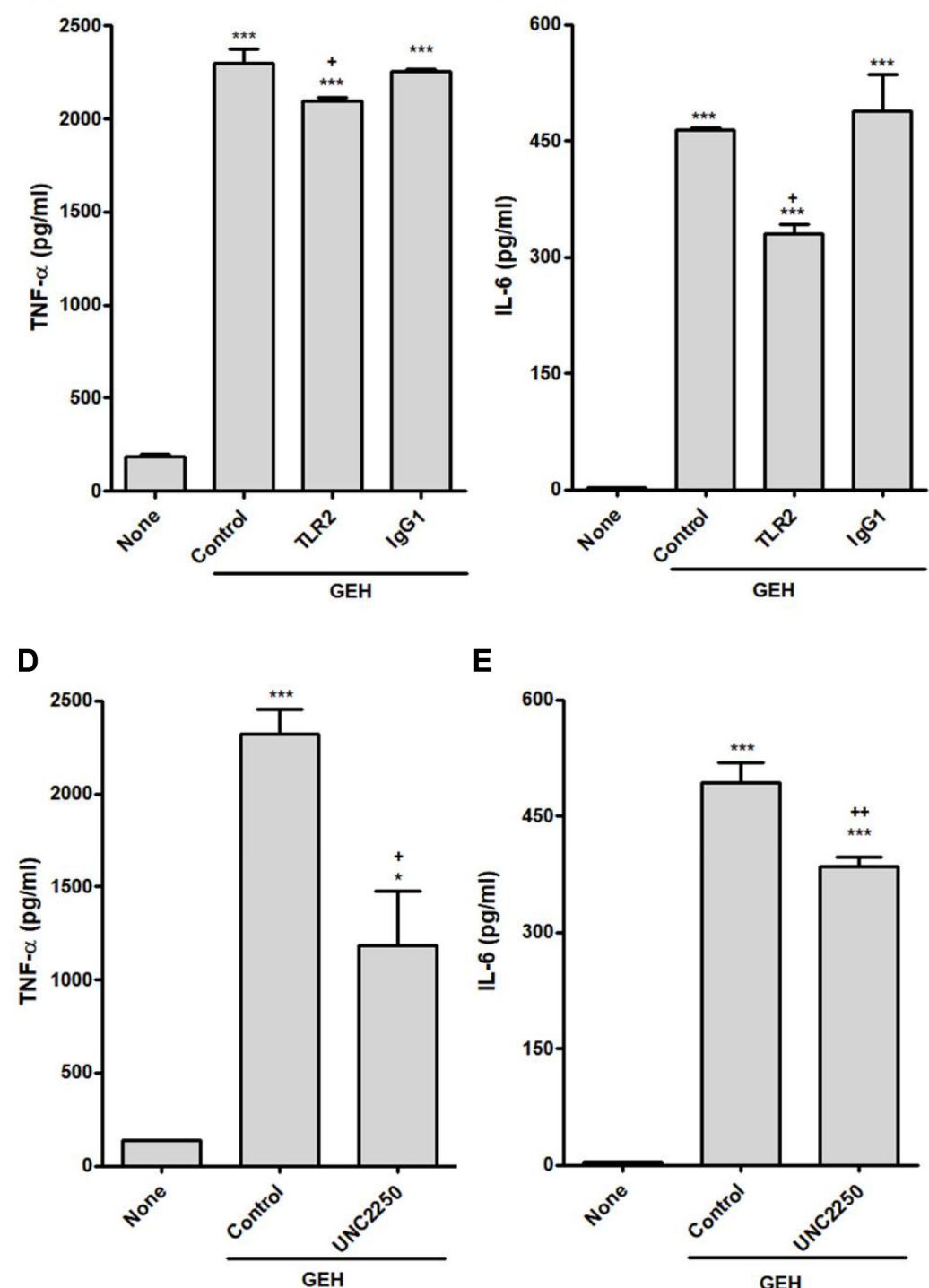

E

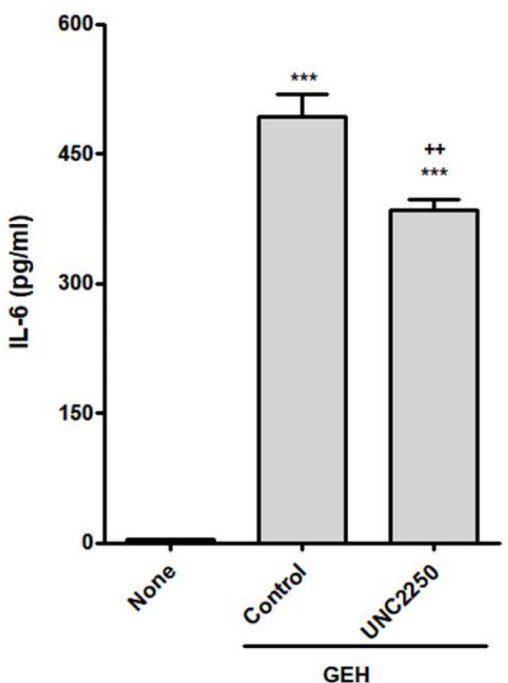

C

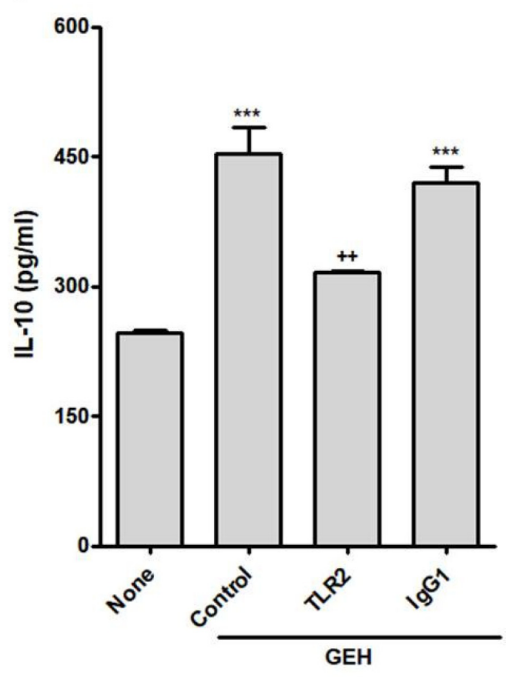

$\mathbf{F}$

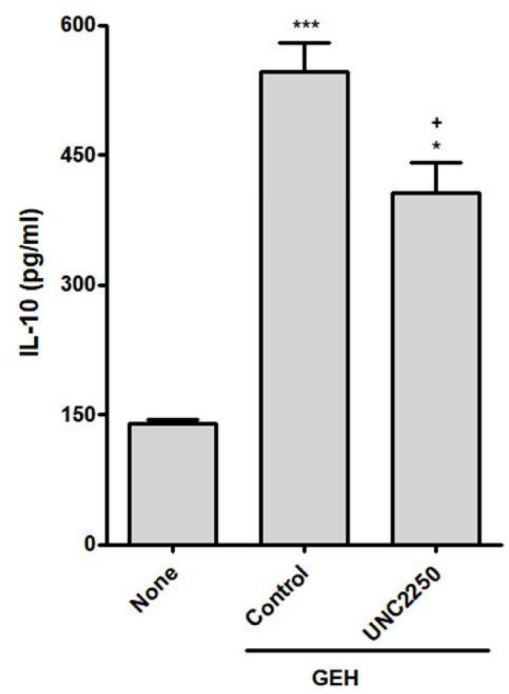

Fig. 10. Association of TLR2 or MerTK with the GEH-induced production of TNF- $\alpha$, IL-6, and IL-10 in RAW264.7 cells.

Cells were pretreated with or without neutralzing antibody against TLR2 or IgG1 (20 $\mathrm{\mu g} / \mathrm{ml}$ each; A, B, and C) or MerTK inhibitor, UNC2205 $(20 \mathrm{nM} ; \mathrm{D}, \mathrm{E}$, and F) for $2 \mathrm{~h}$, followed by further incubation with or without GEH (500 $\mu \mathrm{g} / \mathrm{ml})$ for $24 \mathrm{~h}$. The culture supernatants were analyzed for levels of TNF- $\alpha(\mathbf{A})$, IL-6 (B), and IL-10 (C) using ELISAs. Values are expressed as the mean \pm SEM of three separate experiments. ${ }^{*} p<0.05$, ${ }_{* * *} p<0.001$ compared with the GEH-untreated cells (None) ${ }^{+} p<0.05,{ }^{++} p<0.01$ compared with the GEH-treated cells (Control).

completely inhibit cytokine production of TNF- $\alpha$, IL-6, or IL-10.

\section{Effects of GEH on the Expression of p38, ERK, JNK, and SOCS3 in RAW264.7 Cells}

The downstream signaling of TLR2 and MerTK upon stimulation with GEH treatment was investigated by western blot analysis. The downstream signaling molecules of TLR2, including MAPK, were investigated. As shown in
Fig. 11, the expression levels of phosphorylated p38 (p-p38) and phosphorylated ERK (p-ERK) were dose-dependently increased upon GEH stimulation. Moreover, the expression of SOCS3 (suppressor of cytokine signaling), which is a well-known downstream signaling molecule of MerTK, was also dose-dependently enhanced in GEH-stimulated RAW264. 7 cells.

Taken together, the results of the present study showed that the enzymatic hydrolysate $(\mathrm{GEH})$ of ginseng marc 
A

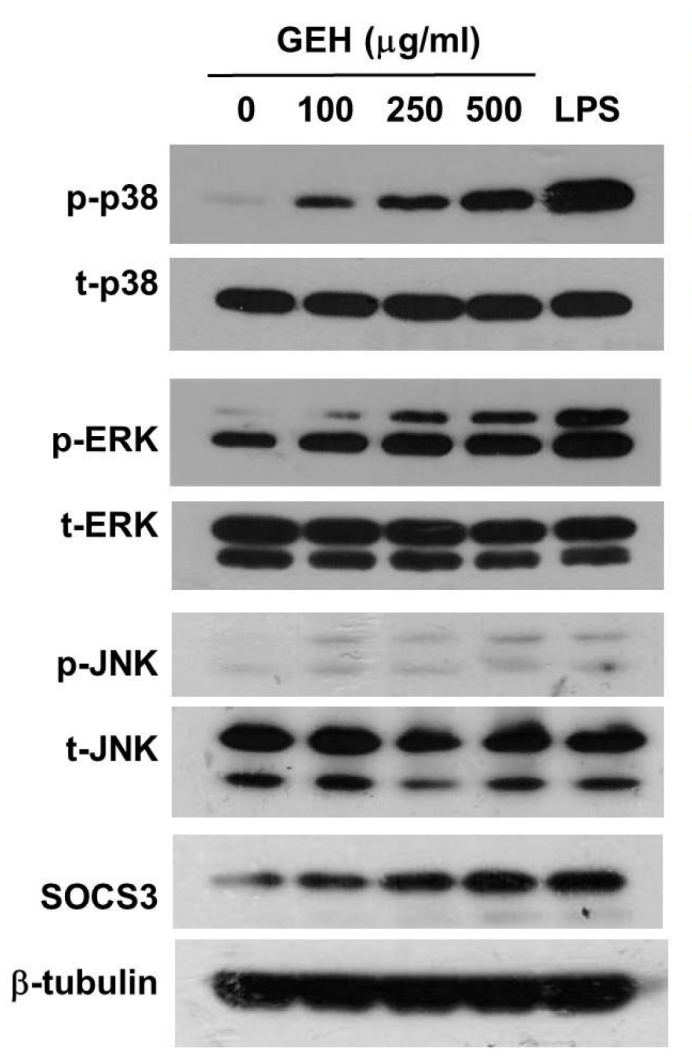

B
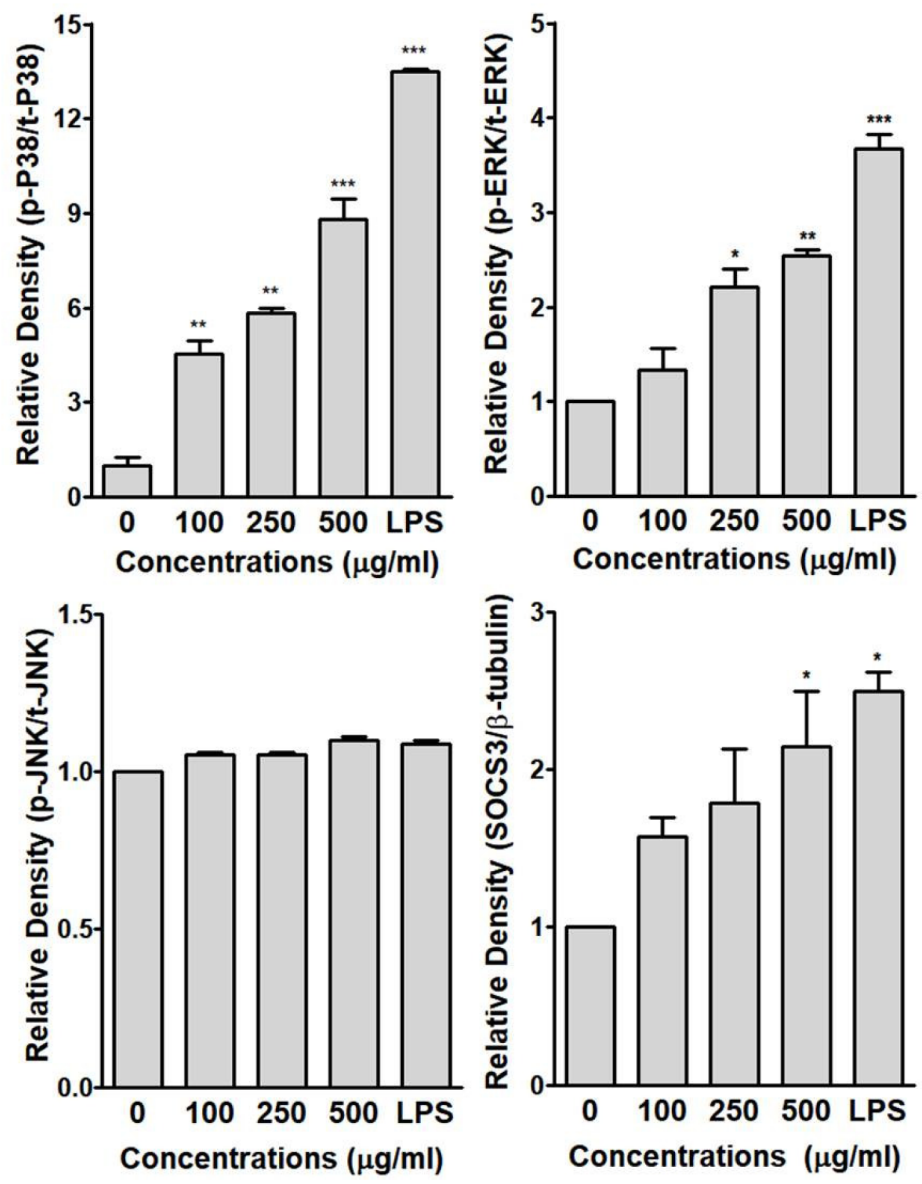

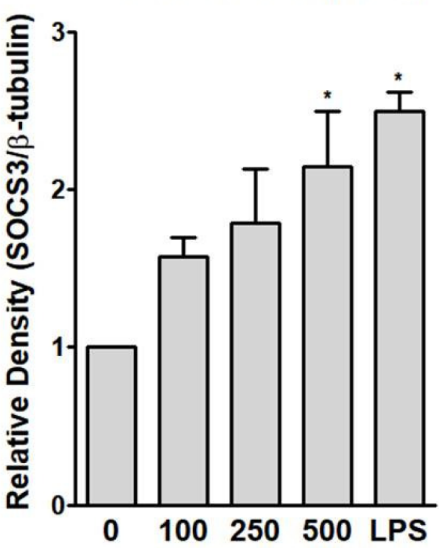

Concentrations $(\mu \mathrm{g} / \mathrm{ml})$

Fig. 11. Effects of GEH on the expression of p38, ERK, JNK, and SOCS3 in RAW264.7 cells.

Cells were treated with different concentrations of GEH for $1 \mathrm{~h}$ (p-p38, p-ERK, and p-JNK) or $24 \mathrm{~h}$ (SOCS3). An equal amount of cell lysates was subjected to western blot analysis. Relative increases in the levels of each band compared with each loading control, total p38, total ERK, total JNK, and $\beta$-tubulin, were quantified using densitometry and ImageJ software. Values are expressed as the mean \pm SEM of three separate experiments. ${ }^{*} p<0.05,{ }^{* *} p<0.01$, and ${ }^{* * *} p<0.001$ compared with the GEH-untreated cells $(0 \mu \mathrm{g} / \mathrm{ml})$.

polysaccharides exert immunostimulatory effects by maintaining the balance between M1 and M2 cytokines, facilitating macrophage activation, and thereby enhancing phagocytic removal of apoptotic cells. Therefore, the GEH could be developed as value-added, health-beneficial food materials with potent immunostimulatory effects.

\section{Acknowledgments}

This study was supported by grants from the Leading Industry Development for Economic Region fund (R0004760), Ministry of Trade, Industry \& Energy (MOTIE), Korea Institute for Advancement of Technology (KIAT), and
Gangwon Institute for Regional Program Evaluation (GWIRPE).

\section{Conflict of Interest}

The authors have no financial conflicts of interest to declare.

\section{References}

1. Attele AS, Wu JA, Yuan C-S. 1999. Ginseng pharmacology: multiple constituents and multiple actions. Biochem. Pharmacol. 58: 1685-1693. 
2. Chang E-J, Park T-K, Han Y-N, Hwang K-H. 2007. Conditioning of the extraction of acidic polysaccharide from red ginseng marc. Korean J. Pharmacogn. 38: 56-61.

3. Hong JK, Bong MH, Park JC, Moon HK, Lee SC, Lee JH, et al. 2012. Effect of feeding red ginseng marc on vital reaction in laying hens under stress task. Korean J. Poult. Sci. 39: 63-70.

4. Ji J, Wang L-C, Wu H, Luan H-M. 2010. Bio-function summary of marine oligosaccharides. Int. J. Biol. 3: 74-86.

5. Guzik TJ, Korbut R, Adamek-Guzik T. 2003. Nitric oxide and superoxide in inflammation and immune regulation. $J$. Phys. Pharm. 54: 469-487.

6. Medzhitov R, Janeway Jr CA. 1997. Innate immunity: impact on the adaptive immune response. Curr. Opin. Immunol. 9: 4-9.

7. Seo JY, Lee CW, Choi DJ, Lee J, Lee JY, Park YI. 2015. Ginseng marc-derived low-molecular weight oligosaccharide inhibits the growth of skin melanoma cells via activation of RAW264.7 cells. Int. Immunopharmacol. 29: 344-353.

8. DuBois M, Gilles KA, Hamilton JK, Rebers Pt, Smith F. 1956. Colorimetric method for determination of sugars and related substances. Anal. Chem. 28: 350-356.

9. Bradford MM. 1976. A rapid and sensitive method for the quantitation of microgram quantities of protein utilizing the principle of protein-dye binding. Anal. Biochem. 72: 248-254.

10. Bligh EG, Dyer WJ. 1959. A rapid method of total lipid extraction and purification. Can. J. Biochem. Physiol. 37: 911-917.

11. Folin O, Denis W. 1912. On phosphotungstic-phosphomolybdic compounds as color reagents. J. Biol. Chem. 12: 239-243.

12. Trouplin V, Boucherit N, Gorvel L, Conti F, Mottola G, Ghigo E. 2013. Bone marrow-derived macrophage production. J. Vis. Exp. 2013: e50966.

13. Ding AH, Nathan CF, Stuehr DJ. 1988. Release of reactive nitrogen intermediates and reactive oxygen intermediates from mouse peritoneal macrophages: comparison of activating cytokines and evidence for independent production. J. Immunol. 141: 2407-2412.

14. Hoffmann PR, deCathelineau AM, Ogden CA, Leverrier Y, Bratton DL, Daleke DL, et al. 2001. Phosphatidylserine (PS) induces PS receptor-mediated macropinocytosis and promotes clearance of apoptotic cells. J. Cell Biol. 155: 649-659.

15. Mills CD, Kincaid K, Alt JM, Heilman MJ, Hill AM. 2000.
M-1/M-2 macrophages and the Th1/Th2 paradigm. J. Immunol. 164: 6166-6173.

16. Mantovani A, Sica A, Sozzani S, Allavena P, Vecchi A, Locati M. 2004. The chemokine system in diverse forms of macrophage activation and polarization. Trends Immunol. 25: 677-686.

17. Rutigliano JA, Graham BS. 2004. Prolonged production of TNF- $\alpha$ exacerbates illness during respiratory syncytial virus infection. J. Immunol. 173: 3408-3417.

18. Herre J, Gordon S, Brown GD. 2004. Dectin-1 and its role in the recognition of beta-glucans by macrophages. Mol. Immunol. 40: 869-876.

19. Rothlin CV, Carrera-Silva EA, Bosurgi L, Ghosh S. 2015. TAM receptor signaling in immune homeostasis. Annu. Rev. Immunol. 33: 355-391.

20. Fadok VA, Laszlo DJ, Noble PW, Weinstein L, Riches DW, Henson PM. 1993. Particle digestibility is required for induction of the phosphatidylserine recognition mechanism used by murine macrophages to phagocytose apoptotic cells. J. Immunol. 151: 4274-4285.

21. Linger RM, Keating AK, Earp HS, Graham DK. 2008. TAM receptor tyrosine kinases: biologic functions, signaling, and potential therapeutic targeting in human cancer. Adv. Cancer Res. 100: 35-83.

22. Scott RS, McMahon EJ, Pop SM, Reap EA, Caricchio R, Cohen PL, et al. 2001. Phagocytosis and clearance of apoptotic cells is mediated by MER. Nature 411: 207-211.

23. Nguyen KQ, Tsou WI, Calarese DA, Kimani SG, Singh S, Hsieh S, et al. 2014. Overexpression of MERTK receptor tyrosine kinase in epithelial cancer cells drives efferocytosis in a gain-of-function capacity. J. Biol. Chem. 289: 25737-25749.

24. Seitz HM, Camenisch TD, Lemke G, Earp HS, Matsushima GK. 2007. Macrophages and dendritic cells use different Axl/ Mertk/Tyro3 receptors in clearance of apoptotic cells. J. Immunol. 178: 5635-5642.

25. Behrens EM, Gadue P, Gong SY, Garrett S, Stein PL, Cohen PL. 2003. The mer receptor tyrosine kinase: expression and function suggest a role in innate immunity. Eur. J. Immunol. 33: 2160-2167. 